\title{
Revelado de manchas latentes: efectividad del luminol y evaluación de su efecto sobre el estudio del DNA.
}

\author{
Development of latent stains: effectiveness of luminol \\ and evaluation of its effect on DNA analysis.
}

A. Castelló Ponce', M. Álvarez Seguí2, M. Miquel Feucht ${ }^{3}$ y F.A. Verdú Pascual 4

RESUMEN

Con frecuencia, las ropas manchadas de sangre durante un acto violento son lavadas para tratar de eliminar los vestigios. El análisis del DNA mediante PCR ha dotado a la criminalística de la posibilidad de estudiar indicios mínimos que, con otros métodos, sería imposible analizar. Este tipo de muestra plantea una mayor dificultad en la detección de la mancha. En el presente trabajo se analiza la sensibilidad del luminol para encontrar manchas de sangre invisibles. Sobre estas manchas se intenta extraer y amplificar DNA. Los resultados indican que el luminol es muy eficaz para detectar indicios invisibles. Además, en las condiciones experimentales con las que se ha elaborado este trabajo, no se produce interferencia del reactivo en la posterior extracción y amplificación del DNA.

Palabras clave: criminalística, luminol, manchas de sangre invisibles, DNA.

\section{ABSTRACT}

Frequently, clothes stained with blood during a violent act are washed to try to eliminate the traces. The analysis of DNA by means of PCR has provided criminalistics with the possibility of studying minimum traces which would be impossible to analyse by other methods. Detection of the stain is extremely difficult in this type of sample. The present paper examines the sensitivity of luminol for finding invisible blood stains, and an attempt is made to extract and amplify DNA from them. The results show that luminol is very efficient for the detection of invisible stains. In the experimental conditions used in this work, the reagent does not interfere in the posterior extraction and amplification of DNA.

Key words: criminalistics, luminol, latent bloodstains, DNA.

Correspondencia: Fernando A. Verdú. U.D. Medicina Legal. Facultat de Medicina i Odontología. Universitat de Valencia EG Av/ Blasco Ibañez, 17. 46010 Valencia. Telefono: 963864165 / 820. Fax: 963864 165. Correo electrónico: fevepa@uv.es

\footnotetext{
1 Doctora en Ciencias Químicas.

2 Doctora en Medicina. Profesora Asociada de Medicina Legal y Forense.

3 Licenciado en Medicina. Profesor colaborador de Medicina Legal y Forense.

4 Profesor Titular de Medicina Legal y Forense.
} 


\section{INTRODUCCIÓN:}

Con mucha frecuencia las personas implicadas en una acción criminal intentan hacer desaparecer cualquier indicio que puede ser utilizado como prueba de su participación en el mismo. Afortunadamente, el análisis de DNA mediante PCR ha proporcionado a la Criminalística la posibilidad de estudiar indicios mínimos que de otra forma sería imposible analizar [I,2].

De hecho, ya se han publicado interesantes trabajos de investigación en los que se consigue extraer y analizar DNA de manchas de sangre que se han intentado eliminar mediante lavado [3].

Sin embargo, en este tipo de muestra se plantea la importante dificultad de la detección de la mancha. Por esta razón se hace imprescindible disponer de métodos de búsqueda cada vez más sensibles, capaces de detectar indicios no visibles. Además es necesario que estos métodos no tengan un efecto adverso sobre el posterior análisis del DNA.

El Luminol es un reactivo muy sensible que permite la búsqueda y localización de manchas de sangre. Debido al método de aplicación, es muy útil cuando se deben estudiar zonas amplias. Además, ya se comprobado que su aplicación sobre manchas de sangre (visibles), no impide el análisis de DNA por PCR $[4,5]$.

Debido a estas características, se puede pensar que el luminol sea el reactivo adecuado para la detección de indicios invisibles. Sobre los indicios que sean localizados se debe estudiar si es posible la extracción y análisis de DNA mediante PCR.

Para comprobar lo anteriormente expuesto, se proponen estos objetivos:

- Determinar la capacidad del luminol para localizar manchas de sangre invisibles. Por ejemplo sobre una tela lavada repetidas veces en lavadora.

- Comprobar si de las manchas que se localicen con luminol se puede extraer y analizar el ADN.

\section{MATERIAL Y MÉTODO:}

\section{Material y Reactivos:}

- Luminol (3 aminophthalhydrazide).

- Perborato de Sodio.

- Carbonato de Sodio.

- Agua destilada.

- Material de vidrio para medida de volúmenes. Refrigerador. Balanza analítica.

- Material y reactivos necesarios para extracción con Chelex 100.

- Material y reactivos para amplificación (locus D IS80).

- Material y reactivos necesarios para electroforesis en gel de agarosa y visualización de resultados.

\section{Método:}

I. Preparación de la muestra:

Obtener sangre por punción venosa (como anticoagulante utilizar EDTA).

Sobre una tela de algodón formar 20 manchas de sangre y dejar que se sequen a temperatura ambiente. Cada mancha contiene 10 gotas de sangre.

\section{2.- PROCEDIMIENTO:}

La tela manchada se ha lavado en la lavadora. Se ha elegido una temperatura de lavado de $30^{\circ} \mathrm{C}$ y se ha utilizado un detergente y un suavizante standard. Tras el lavado se ha dejado secar al aire libre. Después se eligen las muestras como se indica a continuación: 
- Se separan dos manchas de la tela lavada.

- Se almacena una de ellas. Sobre la otra, se aplica el luminol.

2. I.- PRUEBA DE ORIENTACIÓN (LUMINOL):

El luminol se ha preparado siguiendo la fórmula de Grodsky [6]: En cuarto oscuro, se aplica el reactivo mediante un spray sobre una mancha. Se considera que un resultado es positivo, cuando la luminiscencia se observa inmediatamente. Para asegurar la fiabilidad del resultado estarán presentes dos observadores que comprobarán si se produce o no reacción. Se deberán seguir las recomendaciones sobre seguridad que indican las Safety Data Sheets [7].

Después de la prueba, la mancha se deja secar a temperatura ambiente.

Este proceso (lavado-secado-prueba luminol) se repetirá hasta que se obtenga un resultado negativo en la prueba del luminol.

Sobre las muestras que han dado positivo el luminol se procede al análisis de DNA.

\section{2.- ANÁLISIS DEL DNA:}

Para evaluar la posible interferencia del luminol en la extracción de DNA, se intenta extraer tanto de las muestras tratadas con luminol como de las no tratadas. Se utiliza el método de extracción por Chelex (C) 100 [8].

Se ha amplificado el locus DIS80 [3]. Para determinar los resultados de la amplificación se efectúa una electroforesis en gel de agarosa y posterior tinción con bromuro de etidio.

\section{RESULTADOS:}

Los resultados se muestran en las tablas I, 2 y 3 :

TABLA 1: RESULTADOS DE LA PRUEBA DEL LUMINOL SOBRE LAS MUESTRAS LAVADAS

\begin{tabular}{|l|c|c|c|c|c|c|c|c|c|c|c|c||}
\hline NúM. LAVADOS & 0 & 1 & 2 & 3 & 4 & 5 & 6 & 7 & 8 & 9 & 10 & 11 \\
\hline ESTADO MANCHA & $\mathrm{v}$ & $\mathrm{v}$ & $\mathrm{pv}$ & iv & iv & iv & iv & iv & iv & iv & iv & iv \\
\hline LUMINOL & + & + & + & + & + & + & + & + & + & + & + & - \\
\hline
\end{tabular}

$v=$ visible $\quad p v=$ poco visible $\quad$ iv $=$ invisible $\quad+=$ Luminol positivo $\quad$ - =Luminol negativo

TABLA 2: Resultados de LA AMPLIFICACión DEL LOCUS D1S80 EN LAS MUESTRAS LAVADAS

\begin{tabular}{|c|c|c|c|c|c|c|c|c|c|c|}
\hline & \multicolumn{10}{|c|}{ NúMERO dE LAVADOS } \\
\hline & \multicolumn{2}{|c|}{0} & \multicolumn{2}{|c|}{1} & \multicolumn{2}{|c|}{2} & \multicolumn{2}{|c|}{3} & \multicolumn{2}{|c|}{4} \\
\hline & M1 & M2 & M1 & M2 & M1 & M2 & M1 & M2 & M1 & M2 \\
\hline AMPLIFICACIÓN & + & + & + & + & + & + & + & + & - & - \\
\hline
\end{tabular}


TABLA 3: COMPARACIÓN ENTRE LOS RESULTADOS OBTENIDOS EN LA PRUEBA DE ORIENTACIÓN (LUMINOL) Y EL ANÁLISIS DE DNA POR PCR

\begin{tabular}{|c|c|c|c|c|c|c|c|c|c|c|c|c|}
\cline { 2 - 14 } \multicolumn{1}{c|}{} & \multicolumn{10}{c|}{ NúMERO DE LAVADOS } \\
\cline { 2 - 12 } & 0 & 1 & 2 & 3 & 4 & 5 & 6 & 7 & 8 & 9 & 10 & 11 \\
\hline ORIENTACIón & + & + & + & + & + & + & + & + & + & + & + & - \\
\hline DNA & + & + & + & + & - & - & - & - & - & - & - & - \\
\hline
\end{tabular}

\section{DISCUSIÓN:}

- En este trabajo se ha escogido un soporte blanco para facilitar la visualización de las manchas. Obviamente en telas de colores y/o de material más absorbente las manchas serán invisibles con menos lavados.

- Los resultados indican que con luminol se pueden detectar manchas de sangre que ya han sido lavadas 10 veces.

- Por otra parte se consigue extraer y amplificar DNA en las muestras sometidas a I, 2 y 3 lavados.

- Si se compara los resultados obtenidos con luminol con los de estudio de DNA, se puede llegar a la conclusión de que de una muestra de sangre que no se detecte con el reactivo, dificilmente podrá obtener resultados en la extracción y amplificación de DNA.

- No se ha encontrado diferencias en los resultados de amplificación entre las manchas tratadas con luminol y las no tratadas. Se comprueba de nuevo la no interferencia del reactivo en el análisis de DNA por PCR.

\section{CONCLUSION:}

La posibilidad de obtener DNA de muestras mínimas tiene como consecuencia que los métodos de búsqueda de indicios adquieran especial relieve.

El uso de luminol como reactivo de búsqueda tanto en la escena del crimen como en el laboratorio puede resultar muy útil por su capacidad de localizar manchas no visibles y su no interferencia en el análisis de DNA.

\section{AGRADECIMIENTOS:}

Al personal del Laboratorio de Identificación Genética de la Cátedra de Medicina Legal de Granada y al de la Unidad Docente de Medicina Preventiva de Valencia por su inestimable colaboración.

\section{BIBLIOGRAFÍA:}

I.- Villanueva E, Lorente JA: Aplicaciones del ácido desoxirribonucleico (DNA) en Medicina Legal. En: Gisbert Calabuig JA, Medicina Legal y Toxicología $5^{a}$ Ed. Salvat. Barcelona, 1998. pp II77-II8I.

2.- Budowle $B, B$ rown BL: El uso del análisis de ADN en la identificación forense. Forensica 200I;I(I):9-22.

3.- Andrews C, Coquoz R. PCR DNA typing of washed stains. En: Bär W, Fiori A, Rossi U, Advances forensic haemogenetics 5. Berlin: Springer-Verlag, 1994; 343-345.

4.- Gross A M et al. The effect of Luminol on presumptive tests and DNA analysis using the polymerase chain reaction. J. Forensic Science
1999; 44(4):837-40.

5.- Della Manna A, Montpetit S. A novel approach to obtaining reliable PCR results from Luminol treated bloodstains. J. Forensic Science 2000; 45(4):886-90.

6.- James SH., Eckert WG:Interpretation of bloodstains evidence at crime scenes $2^{\mathrm{a}}$ Ed. CRC Press. New York, 1999.

7.- Safety data sheet. Merck Schuchardt, 1998.

8.- Walsh PS, Metzger DA, Higuchi R. Chelex $100 @$ as a medium for simple extraction of DNA for PCR-Based typing from forensic material. Biotechniques 1991; 10(4):506-513. 